\title{
On the volatile acids of cheese
}

\section{Iljenko \& Laskowski}

To cite this article: MM. Iljenko \& Laskowski (1846) On the volatile acids of cheese, Philosophical Magazine Series 3, 28:186, 234-235, DOI: 10.1080/14786444608645409

To link to this article: http://dx.doi.org/10.1080/14786444608645409

$$
\text { 册 Published online: } 30 \text { Apr } 2009 .
$$

Submit your article to this journal

LII Article views: 2

Q View related articles $\asymp$ 
decomposes it, and precipitates chloride of lead. Several analyses yielded the formula $\mathrm{PbCl}, 5 \mathrm{PbO} \mathrm{C}^{4} \mathrm{H}^{3} \mathrm{O}^{3}+15 \mathrm{HO}$.

Iodide and Carbonate of Lead is prepared by digesting carbonate of lead with lodide of lead until the excess of iodide of lead has dissolved. This salt is yellow and insoluble in water. Its formula is $\mathrm{PbI}, \mathrm{PbO}, \mathrm{CO}^{2}$,-Comptes Rendus, p. 1180.

\section{ON THE VOLATILE ACIDS OF CHEESE, BY MM, ILJENKO AND LASKOWSKI.}

The authors cut fifty pounds of Limbourg cheese, which possessed a very strong odour, into small pieces, mixed them with water, and submitted the mixture to distillation in a large alembic, water being occasionally added during several days. By this operation a somewhat turbid ammoniatal liquor was obtained, which was supersatirated with sulphuric acid and again distilled. 'The product was afterwards saturated with barytes water; the salt obtained was evaporated to its crystallizing point; the acid was again separated and converted into a salt of silver. Analysis showed that this volatile acid was entirely valerianic acid.

The residue was afterwards saponified by means of potash, the soap decomposed by potash, and subjected to a fresh distillation, and there was thus obtained an acid liquid which was saturated with barytes and evaporated to crystallize ; it yielded a mixture of several salts of barytes, which were separated by means of their different solubility in water. The rough salt was mixed with seven parts of water and heated to bolling; the caproate of barytes dissolved, and afterwards separated in crystalline tufts of considerable size, whilst the butyrate remained in solution; this was converted into a salt of silver and analysed.

The barytic salts, which were not dissolved by the seven parts of boiling water, were composed of caproate and caprylate of barytes; and they also were separated by their different solubility.

It appears then that cheese contains the following volatile acids :

$\begin{array}{ll}\text { Butyric acid .... } & \mathrm{C}^{4} \mathrm{H}^{6} \mathrm{O}^{2} \\ \text { Valerianic acid. . } & \mathrm{C}^{5} \mathrm{H}^{10} \mathrm{O}^{2} \\ \text { Caproic acid.... } & \mathrm{C}^{6} \mathrm{H}^{12} \mathrm{O}^{2} \\ \text { Caprylic acid ... } & \mathrm{C}^{8} \mathrm{H}^{16} \mathrm{O}^{2} \\ \text { Capric acid ..... } & \mathrm{C}^{20} \mathrm{H}^{20} \mathrm{O}^{2}\end{array}$

Valerianic acid occurs in the largest quantity, and its presence had been previously discovered by $\mathrm{M}$. Balard in the cheese of Roquefort. All these acids, it will be observed, are homologous substances.

The authors also performed some experiments on the fused portion of chelse; they obtained by means of boiling alcohol perfectly crystalline margarine from it; it was fusible at $127^{\circ} \mathrm{Fahr}$, and margaric acid was obtained from it. The rough margarine was mixed with some liquid glycerine. Unaltered caseine was also present, soluble in boiling water and insoluble in alcohol. There was also pre- 
sent lime, a little magnesia, soda, potash, traces of iron, phosphoric acid, chlorine and sulphuric acid.-Journ. de Pharm. et de Ch., Decembre 1845 .

\section{ON THE DOUBLE SALTS OF THE MAgNESIAN GROUP.}

M. J. Isidore Pierre has paid particular attention to the salts of this group, including those of magnesia, oxide of copper, zinc, nickel, cobalt, manganese and iron.

The author observes, that it is well known that Prof. Graham has stated, with respect to the sulphates of the above-named bases, that one of the equivalents of water cannot be eliminated, except at a much higher temperature than is required for the others; that this equivalent may be replaced by an equivalent of a salt, so that the double salt formed contains one equivalent less of water than if each of the two simple sulphates had brought all its water of crystallization into the molecule of the double salt which results from their combination.

M. Pierre states that the results which he has obtained do not confirm those of Prof. Graham; he found that sulphate of zinc contains, as generally admitted, $43 \cdot 72$ per cent., or seven equivalents of water; and he ascertained that by exposing it for a long time to a temperature of $230^{\circ} \mathrm{Fahr}$. and a current of dry air, that it lost 43.6 per cent.; or the whole of its water, which is at variance with Graham's result, who found that it required a heat of $400^{\circ} \mathrm{Fahr}$. to expel the seventh equivalent of water.

Double Sulphate of Zinc and Potash.-This salt is readily prepared by mixing together hot solutions of equivalents of sulphate of zinc and bisulphate of potash, and allowing crystallization to take place. The crystals are beautiful small, milk-white parallelogrammie tables; this salt is soluble in two and a half times its weight of boiling water, but much less soluble in cold water, for it crystallizes abundantly on the cooling even of an hinsaturated solution.

When exposed gradually to a heat of $356^{\circ}$ to $392^{\circ} \mathrm{Fahr}$, it effloresces without fusing in its water of crystallization, which it loses completely and pretty rapidly at this temperature, the amount being 27.49 per cent. The author's analysis gives as the formula of this salt, $\mathrm{ZnO}, \mathrm{SO}^{3}, \mathrm{KaO}, \mathrm{SO}^{3}+7 \mathrm{HO}$, which indicates, as he shows, 27.32 per cent. of water instead of 84.49 , the experimental result.

In this case it is therefore to be remarked, that the sulphate of zinc retains the seven equivalents of water which it possessed in its simple state.

Double Sulphate of Zinc and Magnesia.-M. Pierre observes, that it is generally supposed that these two sulphates may combine in all proportions; having found that sulphate of zinc in the double salt which it forms retains its seven equivalents of water, the author observes that if sulphate of magnesia did the same, the double salt should contain fourteen equivalents of water.

This salt is readily obtained by mixing its equivalents and crystal. lizing; it forms very fine oblique rhombic prisms, which are by 